\title{
Labor Market as a Parameter of Macroeconomic Policies (Case Study with the Northern Republic of Macedonia)
}

\author{
Ilaz Ameti ${ }^{1}$, Xhelal Luma ${ }^{2}$, Jerina Vukaj Nazaj ${ }^{3}$ \\ ${ }^{1}$ Faculty for Bussines Administration, State University of Tetovo, Skopje, Republic of North Macedonia \\ ${ }^{2}$ Food Biotechnology, St. Clement Ohrid University-Bitola, Republic of North Macedonia, Rezidence Republic of Kosova \\ ${ }^{3}$ Faculty for Economy \& Agrobussines, Agricultural University, UBT, Tirana, Republic of Albania
}

Email address:

ilaz.ameti@hotmail.com (I. Ameti)

\section{To cite this article:}

Ilaz Ameti, Xhelal Luma, Jerina Vukaj Nazaj. Labor Market as a Parameter of Macroeconomic Policies (Case Study with the Northern Republic of Macedonia). Journal of Public Policy and Administration. Vol. 3, No. 4, 2019, pp. 82-85. doi: 10.11648/j.jppa.20190304.11

Received: September 6, 2019; Accepted: October 30, 2019; Published: November 19, 2019

\begin{abstract}
The labor market in the Republic of Macedonia is characterized by a high and ongoing unemployment rate. Slow economic growth does not allow the creation of new vacancies nor the maintenance of a stable employment rate. Unemployment is considered the country's main economic problem. In 2016, the average rate of unemployment was $28 \%$. Most of the unemployed belong to the population aged 25 to 49 , which accounts for over $60 \%$ of the total number of unemployed. On the other hand, inflation is also considered a main concern for the economy of the country. Its consequences are less obvious than the consequences of unemployment, but they do bring about also significant losses to the country's economy, leading to the redistribution of wealth between different classes or strata of society, inefficient allocation of production resources as well as the devaluation of our currency. The purpose of this paper is to analyze the relationship and impact of inflation and the economic growth in the unemployment of the Republic of Macedonia
\end{abstract}

Keywords: Employment, Economic Growth, Decision Making, Informal, Programs

\section{Introduction}

Unemployment presents the most drastic form of social inequality. The unemployed are just consumers and a burden for the society as they depend on others. Unemployment has severe consequences for social and economic stability. Countries which have a low rate of unemployment, are also more stable societies, while countries with high unemployment are characterized by social tension and unstable societies. Unemployment, as general social phenomenon, it has been present for a long time in all the countries of the world, no matter their scale of development and their socio-economic regulation. Unemployment as a social phenomenon is have been around the world for a long time and often many countries have been forced to make extremely huge measures to eliminate or overcome this social phenomenon. Unemployment was initially identified as a preference for the unemployed for leave, but since the level of pay offered is lower than they would like for their future, the example of voluntary or willful unemployment, which adversely affects the level of domestic production and economic activity as a whole. The link between unemployment and GDP is provided by Okun's law, which implies that for every $2 \%$ of actual GDP decline relative to potential GDP, the unemployment rate rises by $1 \%$ [9]. Indeed, the real problems of unemployment relate more to involuntary unemployment, that is to say, the unemployment that results from a weak economy unable to employ the labour force, when it is ready to be employed at a decent wage.

Until the eve of the great economic crisis of 1929/1932, the achievement of the goal of full employment was based on classical theory, according to which J. B. Say [3] "The offer automatically creates its own demand", while there were also opposing views of other classics such as Brunner, Guikerman and Meltzer [4] where they emphasized the possibility of partially depositing the revenue generated in time, and consequently the case. of insufficient demand

Say's theory, on the other hand, was later embraced by neo-classics who reinforced the conviction that unemployment was not an object of concern for economic 
theory and politics.

Unemployment, from an economic point of view, represents the most expensive form of exploiting insufficient development factors. Therefore, it is clear that unemployment is not only a category of social policies but also a criterion of economic development. This means that this characteristic of labor, as a major factor of production in a country's economy, gives absolute character to economic losses from unemployment. So, from what has been pointed out, we find that unemployment is not just an economic and social problem, but a complex social problem. It is therefore no coincidence that nowadays, this problem is addressed by a large number of scientists and researchers of various profiles, primarily economists, sociologists, political scientists and psychologists, who view unemployment as a social, economic and social phenomenon. and provide estimates and alternatives to reducing unemployment opportunities. In Macedonia, this phenomenon is emphasised as a large number of young people seek their future elsewhere, unable to find work in their home country.

Therefore, it is reasonable to ask for a detailed analysis and calculation of the active population, jobs and unemployed in our country. Therefore, considering the importance of these, it is a special purpose of this paper to analyze the economic stagnation in the Northern Republic of Macedonia.

\section{Materials and Methodology}

As the main source of this paper that we have provided for analysis we have obtained critical data from the Statistical Office of Northern Macedonia and then from the research papers of many authors mainly in the macroeconomic field, as well as a section we have obtained from the website using the theory analysis method over unemployment as a distinct social phenomenon.

\section{Expected Results}

\subsection{Labor Market in the Northern Republic of Macedonia}

The labor market in the Northern Republic of Macedonia is characterized by high and persistent unemployment. The slow economic growth of this country does not allow the creation of new jobs and a stable employment rate. The working age population in the period 2008-2018 has increased by $38.199 \%(9.6 \%)$, while the total labor force in 2008 was 919.424 , while in 2018 it changed to 957.623 . The number of unemployed persons in 2018 is 198569 persons who are able to work but lack the permanent labor market. The employment rate in last year's SRM is $45.1 \%$ is quite low with an average salary of $\$ 455$ [17] There is a big difference between gender participation in employment. The employment rate of women remains lower than that of men. In 2017 , about $38.90 \%$ of all employees were female and this percentage has changed in 2018 with a percentage of $1.16 \%$ or $39.16 \%$ of the total.
The low employment growth rate is mainly in the processing industry, public administration transport and education. This labor market situation can hardly be explained by the decline in domestic production and the difficulty of the overall economic situation.

Problem inherent in the demand and supply of work in SRM are Problems inherited from the past. The mass privatization of state-owned enterprises after the 1990s, as well as increased competition for a reduced number of jobs forced many people to withdraw from the labor force. Some of the main concerns were: the conversion of many heavy industry enterprises into industrial waste, the mismatch of production structures and organization of the communist period with global ones, the low level of competitiveness of domestic products.

The problems associated with the informal economy is the totality of those legitimate products for which the administration has no data and this leads to a distortion in statistics which makes the analysis of the real economic situation less accurate. The first signs of the informal economy appeared to a large extent in Southeast Europe, and in the northern Republic of Macedonia as well. Informal employment dominates the labor market, with three out of four employed in the informal market. While many are selfemployed or underpaid workers in agriculture, informality still constitutes a major component of the non-agricultural sector. Some of the main causes of the emergence of the informal economy in the transition period are:

1. Massive closure of jobs in the first transition period.

2. Excessive politicization of the state administration and political interference in economic decision-making. Large demographic shifts from rural to urban areas. Drafting of new legislation.

The negative consequences of labor market informality in SRM are:

1. Creates a distortion in statistics, which makes the analysis of the real economic situation.

2. Reduce overall tax revenue by limiting social assistance to low-income people.

3. Competition with formal activities that can create a series of tightening conditions for industry development.

4. Production inputs, especially labor, shift out of the formal economy and this shift may lower the official growth rate of the economy.

5. -Changing monetary indicators.

Among the positive consequences of informality are the informal economy:

1. Operates as a force to neutralize poverty.

2. Creates the possibility of adapting other more efficient ways to organize economic activities and business ventures.

3. It is a case of responding to the state's inability to satisfy basic human needs.

4. It has brought a lot of innovation and innovation to the economy.

The study of the labor market would not be complete if migration were not analyzed, a known phenomenon 
especially in recent years in Macedonia since about $1 / 3$ of the population emigrated after the opening of democracy. A key feature of migration is that it promotes the phenomenon of brain circulation. Emigration, on the other hand, has particularly affected the labor force, leaving it unbalanced. Macedonia as a country is still undergoing a demographic transition from rural to urban areas Professional training in new market conditions, The transformations of which brought about the emergence of a market economy, brought about the need for new levels of qualification in terms of new technologies and services. Labor market research shows that the educational and professional level of the unemployed remains a problematic issue.

\subsection{Active Labor Market Policies in Macedonia}

1. The Government of Northern Macedonia and the Employment Agency have been presenting various active labor market programs with the support of UNDP since 2002. [16]

2. Job Creation Program: This program provides for public works on infrastructure and on the target group to be unskilled jobseekers.

3. Brokerage work program: this program is to inform young unemployed graduates about the opportunities to invest in local business, which will affect their training.

4. Partnership for the Creation of New Jobs: a program envisioning co-operation between the Employment Service Agency and the Economic Chamber of Northern Macedonia.

5. Job clubs: is a program whose activities are: counseling unemployed, developing presentation skills, etc.

6. Target group employment: is a tailored program for groups voluntary unemployed.

\section{Conclusions}

Macroeconomic policies are implemented in order to achieve the main objectives of full employment and sustainable economy:

1. The labor market in the Northern Republic of Macedonia is characterized by high and persistent unemployment.

2. The number of unemployed persons in 2018 is 198569 persons who are capable of working but lacking a viable job market.

3. -RVM employment rate last year is $45.1 \%$ is quite low with an average salary of $\$ 455$.

4. The increase in employment at a low rate is mainly in the processing industry, public transport and education.

5. Problems related to the informal economy is the entirety of those legitimate products for which the administration has no data and this leads to a distortion in statistics.

6. Informal employment dominates the labor market, with three out of four employed in the informal market.

\section{Recommendations}

1. State administration should be depoliticized and avoid interventions in economic decision-making.

2. Improvement of the legal regulation and its implementation methods,

3. Increase the capacity of the market institutions in terms of labor force,

4. Implementation of active labor market measures related to knowledge and qualifications of the workforce and so subsidizing the unemployed.

5. Improving the export of domestic products might have an impact on reducing the unemployment rate.

6. Modernization and specialization of labor market institutions.

7. Financial incentives for expansion of small and medium-sized firms and the transition of businesses from the informal to the formal economy,

8. The Self-Employment Program and the Employment Subsidy Program, which should be increased and also their efficiency,

9. Reduction of government expenditures,

10. Maintaining the stability of the national currency

11. The growth of industrial businesses which are important factors for a stable economy,

12.Learning from the experiences of the countries with a long tradition in the industry sector.

\section{References}

[1] Abraham-Frois, G., (1978) ed., Problematiques de la croissance, Vol. II, Economica, Paris.

[2] Brunner, K., Alex Guikerman and A. H. Meltzer, (1980) "Stagflation, Persistent Unemployment and the Permanence of Economic Shocks", Journal of Monetary Economics, Vol. 6. No 4, oct. pp. 467-92.

[3] Barro, R., (1988) "The persistence of unemployment", American Economic Review, Papers and Procedings.

[4] Banka Popullore e Republikës së Maqedonisë (2014), Indikatorët kryesorë makroekonomik, BPRM, Dhjetor 2014.

[5] Banka Popullore e Republikës së Maqedonisë (2016), Indikatorët kryesorë makroekonomik.

[6] BPRM, Prill 2016. Barro. R. (1995). Inflation and Economic Growth, NBER Working Paper, 5326.

[7] Elmeskov, J. et M. MacFarlan (1993) "Persistence du chômage", Revue Economique de 1"OCDE, No 21, hiver, pp. 64-94.

[8] Elmeskov, J., et K. Pichelman (1993), "Intérpretation du chômage: le rôle de la participation á la vic active", Revue Economique de 1"OCDE, No 21, hiver, pp. 149-151.

[9] Livre Blanc (1993) Commission Europeanne. Malinvaud, E., (1977) "Substitution du capital au travail, evoluition technologique et effets sur l"emploi", Les determinats de l'emploi et du chômage, OCDE, Paris f. 21-24. 
[10] Malinvaud, E., (1977) "The Theory of Unemployment Reconsidered", p. 128. Blackwell-Oxford. Unemployment Problem." NBER Macroeconomics Annual1: 15-89.

[11] Calmfors, L. and J. Drifill (1988). "Bargaining Structure, Corporatism and Macroeconomic Performance." Economic Policy (April): 13-61.

[12] Lindbeck, A. and D. Snower, J., (1988). The InsidersOutsiders Theory of Unemployment Cambridge MA, MIT Press.

[13] Theodoropoulou, S (2008), The Political Economy of Unemployment, Labour Market Institutions and Macroeconomic Policies in Open Economies: The Cases of Germany and the Netherlands in the 1980s and 1990s p 36-64.

[14] Josheski. D and Lazarov. D. (2012). New Keynesian Macroeconomics: Empirically tested in the case of Republic of Macedonia, http://hdl.handle.net/10419/64403.

[15] Samuelson. P. A. and Solow. R. M. (1960). Analytical aspects of anti-inflation policy. American Economic Review. 50 (2), pp. 177-194.

[16] Kostadinov. A, Labour market policies in Macedonia, CEA, Skopje, April 2009, fq. 15-18.

[17] http://www.stat.gov.mk/Publikacii/MakBrojki2019mk.pdf.

[18] https://www.semanticscholar.org/paper/Trade-Liberalisationas-a-Changeability-Factor-in-AmetiAmeti/201c0c03e7f0c63cc0b30091af095908dfa0925b.
[19] https://www.ijires.org/index.php/issues?view=publication\&tas $\mathrm{k}=$ show\&id $=183$.

\section{Biography}

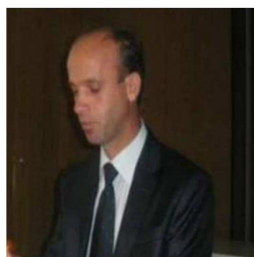

Ilaz Ameti, Faculty for bussines administration, State University of Tetovo, Skopje, Republic of North Macedonia.

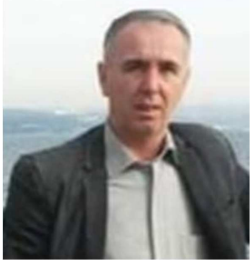

Xhelal Luma, St. Clement Ohrid University of Bitola, Macedonia, Rezidence Republic of Kosova.

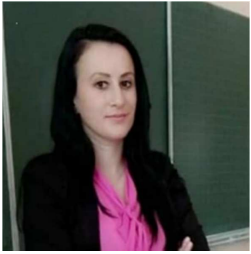

Jerina Vukaj Nazaj is an Assistant Faculty for Economy \& Agrobussines, Agricultural University, UBT, Tirana, Republic of Albania. 